\title{
CAUSE AND EFFECT OF SUFFERING IN SYDNEY SHELDON'S IF TOMORROW COMES
}

\author{
${ }^{1)}$ Muarif Setiawan, ${ }^{2)}$ Efendi Barus, ${ }^{3)}$ Muhammad Ali Pawiro \\ Faculty of Literature \\ Islamic University of North Sumatra, Medan \\ Email: ${ }^{2)}$ efendi_uisu@yahoo.com, ${ }^{3)}$ pawiro@sastra-uisu.ac.id
}

\begin{abstract}
If Tomorrow Comes, a novel written by Sydney Sheldon, is a story of intrigue and revenge. Tracy Whitney is a young, beautiful and intelligent woman and about to marry a wealth man until, suddenly, she is betrayed, framed by a ruthless Mafia gang, and then abandoned by the man she loves. Only her ingenuity saves her and helps her fight back. The significant theme of the novel is suffering, which is the focus of the study with two major points of discussion: the causes and the effects of suffering, subdivided into avarice and loss of trust as a part of the first major point and courage, revenge and hypocrisy as the second major one. The study is conducted with descriptive qualitative method proposed by Dawson (2004) pointing out that qualitative descriptive research is appropriately used to analyze social phenomena. The result shows that the protagonist, Tracy Whitney, faces a lot of suffering from the beginning of the story; that is from the tragic of her mother's death till she is out of jail. All the sufferings are triggered by avarice of a small group of bandits of white collars having a great personal interest who stand against Tracy and loss of trust from her fiancé, the one whom she expects to be with her in time of difficulty. Owing to her sufferings, Tracy becomes strong mentally but she also turns to be revengeful woman of significant hypocrisy.
\end{abstract}

Keywords: suffering, avarice, trust, courage, revenge and hypocrisy. 
Cause and Effect of Suffering in Sydney Sheldon's If Tomorrow Comes, Muarif Setiawan, Efendi Barus, Muhammad Ali Pawiro

\section{INTRODUCTION}

Tomorrow Comes by Sidney Sheldon is a high-octane, sexy thriller that keeps the reader on tip-toe throughout, trying to guess what the next plot twist will be. It is the story of an average American woman, Tracy Whitney, who sets out to avenge her mother's suicide resulting from the loss of her business to con men and criminals in New Orleans. Against seemingly impossible odds, Tracy outwits these career criminals and one by one leads them to their own destruction through clever con games of her own. Her anger sated by these acts of revenge, Tracy is drawn subtly into another world of criminality peopled by hustlers, flimflam artists, burglars and assorted other human parasites. She finds that she has a real gift for this line of work, and soon becomes one of the most wanted female criminals in the world - a one-woman crime wave who never does physical violence to anyone but who lives by outsmarting those who would capture or coopt her. Tracy's satisfaction in executing high-risk, high-reward schemes grows exponentially until it is the central driving force, or addiction, of her life. Her relationships with men are largely superficial one-nighters; it seems she is incapable of truly loving anyone but herself.

The study is conducted by means of qualitative descriptive method proposed by Dawson (2004) and this is an appropriate method conducted as it gives detailed points of some social events.

The focus of the study is on the suffering of the protagonist, Tracy Whitney with two major points of discussion: the causes and the effects of 
suffering, subdivided into avarice and loss of trust as a part of the first major point and courage, revenge and hypocrisy as the second major one.

Suffering can be described as an experience that involves physical and mental pain resulting from a sense of loss, disturbance, or a general feeling of powerlessness surrounding a series of events.

Everything is suffering. Humans define their existence by misery and suffering. Suffering is defined as; to feel pain or distress; sustain loss, injury, harm, or punishment. Even if one is happy they cannot be happy forever, so when they are no longer happy they are suffering. Birth, aging, sickness, death is suffering. Suffering is an elemental fabric of life. (Antonio, 1990: 214)

Avarice is more or less meant a selfish desire to acquire more than one needs or deserves. Avarice is something that just about everyone has. People all want certain, and sometimes some people want more than others. Whether they are rich or poor avarice can exist in everyone. Avarice is more of a bad thing, than a good thing for every person. (Godwin, 2013: 101)

The second cause is the loss of trust. Trust is often stated as believing in someone. However, it is not that simple to understand. It goes into deeper meaning as people continue to live, grow and experience different challenges in life. Trust is believing in someone with heart, knowing that he/she will cherish it as a treasure inside him/her.

Trust is really not easy to earn. It is not given to others but rather, it is earned. It is not something that is as simple as believing. Instead, it involves your believing in each other, knowing that you will not let each other down. (Wall, 2005: 92) 
So great is the significance of trust that the loss of trust could mean the loss of everything. When one loses trust from his or her surroundings then the person concerned has lost the whole world and suffering will surely come. The loss of trust triggers problems which if unsolved will create sufferings

If avarice and loss of trust become the causes of suffering, then some consequences of suffering also emerge from the study. The first is courage. A man of great suffering is usually courageous.

Courage in simple words means an act of bravery. Certainly, that is not just it. Courage takes a bigger picture of an act of bravery. It is about will plus the big word, BELIEVE. When one is courageous enough to do what is right, he earned the utmost respect of human spirit. While some may see being courageous has to be doing a big thing, it boils down to a thing as small as saying "Sorry, I was wrong." (Osho, 2009: 87)

The above concept shows that courage is a weapon armed in everyone's heart. By means of courage respect will come. A true hero is he who possesses courage.

The second effect exposed is revenge. Revenge is a very strong feeling that does not bring joy to people. Motivation for revenge are fighting for justice, seeking satisfaction in repaying the deed with the same coin.

Revenge is a kind of wild justice; which the more man's nature runs to, the more law ought to weed it out. For as for the first wrong, it doth but offend the law; but the revenge of that wrong, putted the law out of office. Certainly, in taking revenge, a man is but even with his enemy; but in passing it over, he is superior; for it is a prince's part to pardon. (Sargent, 2009: 89) 
Throughout history, revenge has stood out as a primal human instinct that has fueled terrible deeds. Though, it often leads one to perform criminal acts, Sargent (2009) argues that it is a necessary component in the functioning of society. He points out that revenge is a threat that acts as a disincentive to undeserved violence. Revenge is an emotion that has not only consumed many, it has been simplified that in all fairness one turn deserves another.

The third effect of suffering is hypocrisy. Hypocrisy refers to the act of claiming to believe something but acting in a different manner.

The act or practice of a hypocrite; a feigning to be what one is not, or to feel what one does not feel; a dissimulation, or a concealment of one's real character, disposition, or motives; especially, the assuming of false appearance of virtue or religion; a simulation of goodness. (Marlow, 2010: 95)

\section{DISCUSSION}

The ecstasy of marrying a wealthy Philadelphian cruelly vanishes when Tracy Whitney faces a prison term. Framed for theft and tricked into a guilty plea, Tracy wastes no time in planning to avenge her wrongdoers and ease the pain of her mother's untimely death. A full pardon from the Louisiana governor frees her to affect suitable retributions.

Each white-collar swindle propels Tracy to another, allowing her to gain dubious skills as a remarkably clever, beautiful, and elusive woman. Lurking in her shadow, however, is Daniel Cooper, an insurance investigator obsessed with 
Cause and Effect of Suffering in Sydney Sheldon's If Tomorrow Comes, Muarif Setiawan, Efendi Barus, Muhammad Ali Pawiro

capturing Tracy and returning her to prison. His obnoxious demeanor weakens his credibility with officials despite the accuracy of his leads.

The only other match for Tracy is Jeff Stevens, whose exploits are woven around those of Tracy. In Madrid, the competition between them ceases as Jeff outwits Tracy by delivering her stolen painting to their mutual contact. This final finesse sparks her anger but also compels her unqualified love and respect.

\section{Causes of suffering}

\section{Avarice}

The matter of avarice is highlighted in the novel through a mobster man named Joe Romano and this man has caused the sufferings of Tracy and her mother. Avarice is largely related to any action of manipulating and dominating others by using the tools of power and money based on a never-ending greediness.

At the very same time, Tracy Whitney is vividly pictured as a real prey of the avarice of a mobster group. First, her mother is driven to a suicide on the account of the avarice of a man. Her mother apparently feels frustrated, hopeless and useless since she has been taken in by Joe Romano. Her mother has been conned by him. Her mother must voluntarily give up her company her late husband has left her to Joe Romano, and not only that, she also has to pay a half million dollars for being accused guilty of fake documents by the district attorney.

You have already falsified all the documents of the company and therefore I could sue you to the court. You have to pay me, half of the company. I, Romano, am 
already kind to you but in if you do something against me then you will know. (Sheldon, 2000: 121)

This proves that Romano, urged by his avarice has trapped Tracy's mother. As regards to his accusation, her mother goes bankrupt and terminates herself in a suicide. This reality becomes the hardest blow for Tracy Whitney and not mentions what Perry Pope and Judge Henry Lawrence have done to her, deteriorating her life.

In this case what Romano does to Tracy's mother is a kind of blackmail. Blackmail is the crime of threatening to reveal embarrassing, disgraceful or damaging information about a person to the public, family, spouse or associates unless money is paid to purchase silence. It is a form of extortion.

Knowing that her mother's demise is not right, she then comes to Romano's house to get an explanation. Her coming to Romano's house is urged by her emotional impulse that she brings a gun with her to frighten him and apparently that day is not her lucky day as she accidently pulls the trigger and shoots down Romano. As said before, Tracy brings the gun to frighten and force him to confess all what he has done to her mother and her family. And she does not intend to use the gun to shoot Romano if only Romano does not attack and try to rape her.

Your Honor, it wasn't murder. I shot him, it was an accident, I only meant to frighten him. He tried to rape me. (Sheldon, 2000: 40)

The above quotation is Tracy's defensive statement in the hearing session in the court. On the contrary, the district attorney does not accept what she has 
said before the court but accuses her of robbery and murder, even though Romano has been dead yet.

'Your Honor, I see no point in wasting the court's time. This woman broke into Mr. Romano's house, armed with a thirty two caliber revolver, stole a Renoir painting worth half a million dollar, and when Mr. Romano caught her in the act, she shot him in cold blood and left him for dead. (Sheldon, 2000: 42)

Hearing this, Tracy is shocked to death and feels the color draining from her face and reiterates that it is not making any sense to her. Tracy is really angry and she never thinks before that the district attorney will twist the case. Indeed, the attorney, owing to his avarice, is also expecting that he would get the share from the remains of the company.

The real problem is that Tracy, in the court, not represented by a counsel and indeed it makes the prosecutor feel a lot easier to make a fool of her. However, the district attorney people seem to have a great intention of making an immense pressure on Tracy. She never realizes that all of them are Romano's people. Since a counsel or lawyer does represent Tracy, the court will appoint one for her.

The name of the attorney appointed by the court is Perry Pope. Tracy comes to know what Joe Romano really is. Joe Romano is the hit man of a mobster leader named Anthony Orsatti. The Orsatti's family practically controls and owns the entire city and the government officials have not bit bravery to 
stop the business of this Orsatti's illegal business. It is through Joe Romano, as the top man in the organization, runs all the business of Orsatti.

Perry Pope tries to ensure Tracy that he is doing to help her out of the problem if only she could tell him how all the things happen, and he also promises to get them all behind the bars as it is quoted here.

I'm going to try. I'd give anything to put them all behind bars. They own this town and most of the judges in it. If you go to trial, they'll bury you so deep and you'll never see the day light again. Then, tell me what else do you have from your father? All is to be clear then, that I could easily manage the strategy. (Sheldon, 2000: 47)

His words are so convincing to her that she believes what he says about saving her, though she does not realize that there is a hidden standing of avarice in Pople's sentences. Pople tells her that he will recommend a judge who is not always in the favor of Orsatti and his people, therefore, recommend Henry Lawrence, the one who hates Orsatti and his gangs. As it is seen in the following:

I don't want to put you in front of a jury because, believe me, it will be his jury. There's only one judge Orsatti has never been able to buy. His name is Henry Lawrence. If I can arrange for him to hear this. I'm pretty sure I can make a deal for you, you know deal? Sure I think you understand that. It's not strictly ethical but I'm going to speak to him privately. He hates Orsatti and Romano as much as I do. Now all we've got to judge Lawrence. (Sheldon, 2000: 43)

One thing is for sure that Tracy does not realize from the very first time that Perry Pope and Henry Lawrence are Orsatti's minions who will devotedly work on his behalf in managing his interest and all of his business at the same time they are also expecting something from Tracy, a sign of avarice. Tracy is 
Cause and Effect of Suffering in Sydney Sheldon's If Tomorrow Comes, Muarif Setiawan, Efendi Barus, Muhammad Ali Pawiro

carried away by Pope's expertise to convince her following his misleading advice and ways.

It is quite obvious then that Romano's avarice here is vehemently dominating in crushing Tracy's fate of life. As regards to the court trial, it is wholly set up by Romano as to demolish Tracy's life in jail. Romano does not want the real happening comes to surface and that is why he must stop Tracy.

Perry Pope eagerly would like to persuade Tracy to accept a guilty plea unconditionally as they think that Judge Henry Lawrence can minimize her punishment. If she is in favor with that she will be only sentence in three months only and approved to do her probation out of the state. Being caught in a vehement confusion, Tracy accepts the offer and hopes that she will not be punished much longer than that.

Tracy takes the deal since Perry Pope has told her that judge Henry Lawrence agrees not to charge her on attempting murder and robbery. However, it results so differently that when Judge Henry Lawrence abruptly claims Tracy guilty.

The defendant has admitted that she attempted to murder of the outstanding citizen of this community - a man noted for his philanthropy and good works. The defendant shot while in the act of stealing an art object worth half a million dollars. (Sheldon, 2000: 48)

Tracy feels herself numb and soon realizes that Perry Pope and Henry Lawrence have tricked her and this happens because they do not see any clue that Tracy will give them money. Their avarice makes them inhuman. As said 
before, Tracy does believe that Henry Lawrence and Perry Pope will help her out of or at least attempt to minimize her punishment, but the fact leads to her destruction. Here Tracy realizes that she has been betrayed. The one whom she thinks to be a friend turns out to be a monstrous enemy.

Indeed, Romano's avarice has produced a severe loss on the side of Tracy's family. The fact is that Tracy would have never thought that the matter would go beyond her inner consciousness. It is something that she cannot comprehend at all. It is, however, going without saying that Tracy can be easily manipulated and cheated because Tracy is an innocent woman who knows nothing about legal things.

So in short avarice is the one behind all the sufferings of Tracy. She is trapped because she has wealth from her father and makes others green in eyes until causing avarice. The avarice of Romano and all his friends towards the wealth of Tracy's family finally brings disaster not only to Tracy but also to Romano especially as he has to pay his avarice with his death.

\section{Loss of Trust}

The matter of loss of trust refers to Charles Stanhope III, Tracy's fiancé who has caused the sufferings of Tracy as Charles does not believe her with no logical reason. She carries his baby but Charles seems to ignore the baby and he is unwilling to know any type of description of the current situation Tracy is facing. He even does not try to find a solution to calm down the crucial situation Tracy is facing now and Tracy pitifully still hopes that Charles will help her out 
of the difficulty. When Tracy is put in jail, she is sure that her dear Charles will come to set her free.

Charles will get me out, she kept repeating to herself. Oh, please, God, let Charles get me out. I can't have our baby born in prison. (Sheldon, 2000: 43)

Tracy has strong confidence that Charles will help to find justice. She thinks that Charles loves her very much. Tracy even plans to get married next month. Tracy does not have any doubt on Charles. She tries to contact him, to inform him the real situation. She is shocked when she finds out that Charles completely does not believe her anymore.

My God, if you needed money that badly, you should have discussed it with me ... any trying to kill someone ... I can't believe this. Neither can my parents. You are the headline in this morning's Philadelphia Daily News. This is the first time a breath of scandal has ever touched the Stanhope family. (Sheldon, 2000: 45)

This shows that Tracy has lost trust from her fiancé, Charles. Charles cannot accept what Tracy does although she defensively tries to tell him the truth. Tracy's problem humiliates his family's name that he does not want to give a hand to her. The world is falling on her now. She feels more alone than she has ever felt in her life. There is no one to turn to now, no one.

Loss of trust constitutes one of the causes of Tracy's sufferings. The unwillingness to believe in Tracy deeply hurts her feeling. Her life falls apart. Her dream to marry and have a baby to care is gone away. To a certain extent, Charles has also victimized her. 
Charles' family does not approve to his making a relationship with Tracy as now Tracy has been convicted as an armed robber and killer. Again loss of trust becomes a trigger of Tracy's love relationship with Charles.

\section{Effects of Suffering}

\section{Courage}

Tracy is sexually assaulted by her cell mates. On the very first day she is in prison, she gets a hard fist smash into her face and another into her stomach and she feels thousand of stars are moving around her. She feels her night gown and underpants are being ripped and two hands grabbing at her breast. Her legs are spread apart and a hard, cold object is shoved inside her. Fist pounds her face and she sinks into the pain, deeper and deeper until finally she feels nothing; she is totally numb.

She is alone in the dark now. Tracy's memory of having lost her baby and her mother affects her emotion. She swears to take revenge upon the death of her mother. Her decision to take revenge upon the accomplices of Romano is a whip for her and then she must handle her emotion and do something carefully. Courage is needed and she begins to grasp courage. She has to stop being a coward now.

Her thoughts burned and blazed until her mind was empty of every emotion but one: vengeance. It was not a vengeance directed against her three cell mates. They were all the victims as much as she. She was after the men who had done this to her, who had destroyed her life. She was going to make them pay. Every one of them. She has no idea how. But she knew she was going to get revenge. Tomorrow, if tomorrow comes. (Sheldon, 2000: 64) 
Cause and Effect of Suffering in Sydney Sheldon's If Tomorrow Comes, Muarif Setiawan, Efendi Barus, Muhammad Ali Pawiro

This shows that her spirit of courage begins to form. Although she feels pain full of suffering she has to be strong and courageous. Tracy has a capacity of hope for tomorrow. She believes that hope will be rising. She has a positive thinking, confidence and hard will. Besides, she has intelligence, she also has a hard will and that is pushed by her newly-come courage.

I will survive. I face mine enemies naked and my courage is my shield. (Sheldon, 2000: 66)

She realizes she must be strong, tough and courageous to face the reality of her life now. She will survive as her ancestors have survived from famine, plagues and floods and she is going to survive this. She knows that she must rise. And there is no one to be afraid of; no one con her anymore because she is different now. She never needs Charles again or anyone else.

Tracy knows that the first thing she has to do is to regain her physical strength. The cell is too cramped for extensive exercise but it is large enough for Tai Chi Chuan, the century-old martial art that is thought by warriors to prepare them for combat. This is the martial art.

Grabs the bird's tail, become the white stork, repulse the monkey, face the tiger, let your hands become clouds and circulate the water of life. Let the white snake creep down, and ride the tiger. Shoot the tiger, gather your $\mathrm{Chi}$ and go back to the Tan Tien, the center. (Sheldon, 2000: 65)

That is the first awakening of Tracy. She goes through the ritual each morning and afternoon until her body begins to respond and grows strongly. 
Tracy has no idea how many prisoners have been broken by their confinement in the solitary cell.

When the matron releases her from the confinement, she really gets surprised as Tracy could arise easily to her feet and walk out the cell without being aided. She goes back to her cell while her cell mates go to work. She reaches down to the bottom of her bunk and pries of the metal side loose. She is ready for them. When they come at her, she lifts the piece of metal she has concealed in her hand and swing with her power, hitting them in the face. There is a scream of pain and Tracy kicks out and sees them fall to the floor, "Come near me again, and I'll kill you." (Sheldon, 2000: 67)

This shows that Tracy has become a true courageous woman. There is no more a shy or weakness. She gets guts. All the sufferings she has faced have turned her into a courageous woman. She is now standing on her own feet with marvelous confidence. Her life in prison makes her understand about the outside world that she never knows before. She learns so many things while in prison. The prison is filled with expert in every conceivable type of crime. They exchange method of grafting, shoplifting and rolling drunks and also they exchange information on snitches and undercover cops.

\section{Revenge}

Tracy plans to take revenge on Romano's accomplices as they have buried her deep in the prison life. In every blow of her breath, she is thinking of 
Cause and Effect of Suffering in Sydney Sheldon's If Tomorrow Comes, Muarif Setiawan, Efendi Barus, Muhammad Ali Pawiro

revenge. She cannot forget them, and she cannot give any feeling of sympathy. Her mind has already been filled by various strategies to take revenge.

In reality Tracy has been finished by a mobster group; not only Tracy but also her mother. Romano is the chef for the criminal recipe given to Tracy. And she is hopeless as she is alone. She is powerless as she is neglected. She is frustrated as all the court officials are against her.

Tracy is now out of prison; she is released by the recommendation of the Warden. Now she makes a good plan to finish all those who have destroyed her: Perry Pope, Henry Lawrence, Anthony Orsatti and even Charles Stanhope III, her fiancé.

Tracy knows that Romano is much loved by Orsatti and already considered to be his son. Tracy, disguising herself as Romano's lover calls Orsatti, telling her that Romano has left her a bank account of a handsome sum of money, taken from Orsatti and she tells Orsatti that she wishes to return the money before going to Brazil. Anthony Orsatti feels disappointed hearing this as he never dreams that Romano could cheat him and he also never imagines how he could be easily cheated by his own trusted man.

I'd been like a father to Joe Romano. I trust him, made him my man. And the son of a bitch stabbed me in the back. If that dizzy French dame hadn't telephoned, I would never have known this. And the bitch never comes to see me, let her fuck around with the fish down there. (Sheldon, 2000: 134) 
Tracy also knows for sure that she cannot directly come to kill Orsatti as Orsatti is surrounded by strong people, loyal guards. This is a suicide so Tracy just makes Orsatti hurt in feeling and as a boss his prestige is really disturbed for being easily cheated by his subordinate. Then the next disappointment Tracy gives to Orsatti is she never keeps her promise to return the money and she never shows up before Orsatti.

The next victim of her revenge is Perry Pope. The weekly Friday night poker game at Pope's house is an event to which many players look forward. In the afternoon the central air conditioning machines trails off into silence, meaning that the machine stops working being broken down by Tracy's friends stealthily. Tracy's friends disguised as technicians come to repair the air conditioning machine and while working they put some sharp metal on the attic. They also put some hamsters there and make a peephole on the ceiling. As they start the poker game, a small piece of particle falls into Pope's coffee caused by the hamsters. Pope looks up at the ceiling and when this happens, the sharp glasses hit him of the forehead causing a bad accident on him. He is seriously bleeding and his eyes are totally blinded by the sharp pieces of metal.

Poor Pope, how could such a thing happen in his house? He is really a fool letting the machine without being repaired. He could work no more. He will walk along the street, begging for food. (Sheldon, 2000: 121)

Everyone feels pity on Pope and everyone talks of the accident but none of their talk is directed to Tracy. Tracy is safe and sound with all her revenge and by career Pope is finished now and he cannot go to the court to practice law. He 
Cause and Effect of Suffering in Sydney Sheldon's If Tomorrow Comes, Muarif Setiawan, Efendi Barus, Muhammad Ali Pawiro

has to retire and become a disable person. This is revenge from Tracy. Tracy does not want to kill him as she knows that through a deep crime investigation she could be found out. And now no one suspects her and in fact there is no suspicion at all in what happens to Pope as everyone says that it is just an accident caused by parts of the air conditioning machine.

Then, it comes the fate of Henry Lawrence. Lawrence is in Moscow but Tracy could tracks him. Tracy sends a paid cable in code to Lawrence and informs the Russian Interpol that Lawrence tries to obtain information of the new Russian ship soon. As the code is made in such a tricky and clever way the Russian side trusts the information and they arrest Lawrence as an American espionage. He is cringing like a terrified creature that grovels to them. And he is almost going insane denying the accusation.

Why are they doing this to me?, Lawrence croaked. I'm an American citizen. I am a judge. For God's sake, get me out of here. I do nothing to you all. Please. (Sheldon, 2000: 139)

Lawrence is sentenced to Siberia for fourteen years of hard labour. There of her enemies have been beaten down and anyhow Orsatti though in consideration will be the last.

For Charles, Tracy does not do any harm to him as Tracy comes to learn that Charles has been in great suffering since his marriage with a girl chosen by his mother. The couple are not in good terms and both of them are happy in marriage. From the look, Charles is in a mess and Tracy thinks that this is already enough for Charles. Charles has got his own punishment by ignoring her while in 
prison. However, Tracy is basically not a bad person. She is once in love with Charles and as a good person she has her own principle.

\section{Hypocrisy}

Tracy is satisfied for what she has done to her enemies. Now she has to earn money, meaning that she has to find a job. She wishes to be a good person as she has already got a plan to turn a new leaf. She tries to apply back to her previous job, that is in a bank but unfortunately the bank rejects her as they know that Tracy has already ever been in jail and they do not want to hire an exprisoner.

I'm sorry but what you're asking is quite out of the question, I'm sure you can understand that our customer would not wish to deal with someone who serves time in penitentiary for armed robbery and attempted murder. I think it unlikely that given your background, any bank would hire you. (Sheldon, 2000, 154)

This really hurts Tracy's feeling. Living as an ex-prisoner is the hardest thing in her life. She is suggested to find a job suitable with her condition. At first, she feels shocked and then her anger grows. People make her sound like an outcast, a leper. She cannot let them do this to her. Her pride is all she has left and no one is going to take it away from her. She owes that to herself. She never thinks and even ever dreams that people will not welcome her anymore.

Then she comes to Conrad Morgan who likes to give a hand to people who have been in prison. Morgan offers her to be a thief but she refuses him at first. She will never put herself to be a criminal even she has a very little money left. 
Cause and Effect of Suffering in Sydney Sheldon's If Tomorrow Comes, Muarif Setiawan, Efendi Barus, Muhammad Ali Pawiro

No one easily trusts her as she is an ex-prisoner. That is her life and she has to struggle hard now, at least to get a trust from people. A suspicious thought always follows in every step she makes. She has read of convicts being hounded because they have prison records but it has never occurred to her that this kind of thing could happen to her. They have stuck a label on her and they expect her to live up to it or down to it. She is always rejected wherever she tries to find a job even as a housekeeper she is still rejected. Then she begins to think that if she becomes a thief, that is not her wish but the wish of the people.

She goes back to Morgan taking his offer. To get twenty five thousand dollar cash on delivery for two hour work is tempting her now. it is fortune enough to take care of her until she could figure out what to do with her life. She things of the dreary little room she lives in, of the screaming tenants and the customer yelling that she does not want a murderess waiting on her.

The plan now is to rob a rich woman, Mrs. Bellamy, whose house is filled with expensive things. Besides, she is insured for twice the amount the jewels are worth. And this time, Mrs. Bellamy has gone to Europe and her house is empty as on weekends the servants are off, so there is no one there.

Jeff thinks Tracy is the most ingenious hypocrite he ever sees. A scam tricks a scam. Morgan tells him that the woman is an amateur but what he finds out is the opposite thing.

'My God,' Jeff thought, 'what would she be like if she were a professional?' (Sheldon, 2000: 181) 
This shows that Tracy has become a smart hypocrite. Her dreams, wishes and life are broken miserably by some immortal attitudes of people, by people who take some advantages from her. They have taught her to be a professional thief. She never allows anyone to trick her anymore now.

There is one thing special with her; Tracy never hurts her victims. Stealing and lying now have become her specialization. And most of her victims are not good people. They are all corruptive.

She was careful never to hurt the innocent. The people who jumped at her swindles are greedy or immoral, or both. No one will ever commit suicide because of what I've done to them - this is what Tracy says to herself. (Sheldon, 2000: 245)

Though she is a criminal, deep in her heart she is still the good Tracy, who actually does not want to hurt others. Naturally she is a kind woman, an innocent lady who is forced to be a thief and hypocrite. She is generous. She has accumulated more money than she will ever need. And she sets up a fund from which she makes large, anonymous contributions to several organizations that help former woman prisoners and she arranges for a generous pension to be sent every month to Otto Scmidt, a man who helps her mother when she is alive.

She has everything she needs now. She has money in safe, deposit boxes all over Europe, a house in London and a chalet in St. Moritz. All is with her except someone to share with. Tracy thinks about the life she almost has, with a husband and a baby but it seems that would not be possible. She can never reveal 
to anyone who she is in reality, nor could she live a lie by concealing her past.

She has played so many parts in her life and all the parts are dark.

She checked herself in the mirror before she left the quarters, staring at her reflection for a long time. Her green eyes had a look of innocence and her face looked guiltless and vulnerable. 'The mirror is lying. I'm not that woman anymore. I'm living a masquerade but an exciting one.' (Sheldon, 2000: 257)

She is no longer sure who she is in reality. Sometimes she thinks that she is a lucky one. A lot of people are lonely and she is not the only one who always feels lonely. This at least could comfort her. Ex-convicts do not live an easy lifestyle in prison, however, when they reenter society, they have even bigger struggles to face. In the outside world ex-convicts do not face the intimidation of other convicts, but rather disrespectful and pessimistic attitudes from employers. Ex-convicts are immediately judged and labeled based off of their rap sheet. What these employers seem to forget is that, these ex-convicts are people trying to make a living as well.

\section{CONCLUSION}

The protagonist of the novel, Tracy, owing to her ignorance of matters of lawsuit could be easily trapped in tricky ways. And she has to suffer a lot. And even she has to pass her time in prison as she is accused of armed robbery and murder. Her sufferings are caused by avarice from the side of her enemies and loss of trust from a person whom she expects to be at her side in time of difficulty and this person is her fiancé, Charles Stanhope III. Tracy tries to ensure 
Charles that she is not guilty in all the indictments given to her but to her disappointment Charles does not believe her.

And surely life in prison is hard but Tracy could pass all her difficulties. And this is the effects of her suffering. She becomes a courageous woman as she thinks that the only weapon she has to possess is to gain courage. Courage will solve a problem. She then becomes a revengeful person. She cannot forgive all that has been done to her by her opponents and the moment she is out of jail, she begins to make a scheme of her revenge and she succeeds.

As an ex-prisoner, Tracy finds a lot of obstacle to continue her life outside the jail. People do not trust her anymore and even they think that Tracy is a dangerous woman and has to be avoided. She tries to get a job, a good and legal job and actually she does not choose a certain job to be attended to but all comes in vain as no one could easily accept an ex-prisoner in their business. Finally circumstances force her to be a hypocrite. She begins her business by cheating and one after another falls into her victims. Apart from all the bad things Tracy is doing, she still has heart to show empathy. She helps the poor from the money she gets by cheating and she also helps the female ex-prisoners to find a better job. 
Cause and Effect of Suffering in Sydney Sheldon's If Tomorrow Comes, Muarif Setiawan, Efendi Barus, Muhammad Ali Pawiro

\section{REFERENCES}

Antonio, H. (1990). Victims and Values: A History and a Theory of Suffering. New York: Praeger.

Dawson, Smith. (2004). Descriptive Qualitative Approach. New York: Velmont Press.

Godwin, William. (2013). Of Avarice and Profusion. London: University Press.

Marlow, Steven. (2010). Hypocrisy. New York: Griffin.

Osho. (2009). Courage: The Joy of Living Dangerously. London: Griffin.

Wall, Cynthia Lynn. (2005). The Courage to Trust. New York: New Harbinger Publications

Sargent, Rose-Mary. (2009). Selected Philosophical Works of Bacon. London: Hackett.

Sheldon, Sydney. (2000). If Tomorrow Comes. New York: Harper. 